DOI https://doi.org/10.30525/978-9934-26-114-5-64

\title{
ІНТЕГРОВАНИЙ ПІДХІД ДО НАВЧАННЯ У ДИТЯЧІЙ АКАДЕМІЇ «ФУТУРУМ»: НЕСТАНДАРТНІ ЗАНЯТТЯ
}

\author{
Шевченко І. М. \\ методист кабінету експериментальних освітніх методик \\ Національний центр «Мала академія наук Украйни» \\ м. Київ, Украӥна
}

Пріоритетним напрямом сучасної системи освіти на сьогодні $\epsilon$ формування у дітей і молоді цілісної наукової картини світу і сучасного світогляду. 3 народження дитина пізнає світ системно, але згодом цей процес ускладнюється, природній інтерес до власних пошуків стає не таким активним. У Концепції Нової української школи зазначається, що освітній заклад має забезпечити розвиток світогляду особистості, не порушуючи природне світосприйняття, наголошено на необхідності формування компетентностей, основою яких є цілісна картина світу, де інформація впорядковується, доповнюється, змінюється і трансформується у цілісну систему. Природничо-наукова освіта закладає основи пізнання образу світу і власне себе, пошукового мислення, стійкого інтересу до життєтворчості, формування цінностей, пошуку особистісної самореалізації і професійного самовизначення. Низка цих питань потребує пошуку ефективних шляхів вирішення проблем, які постали перед педагогічною спільнотою, а саме: формування освітнього середовища як відкритої соціально-педагогічної системи, яка базується на принципах наступності, науковості, інтегрованості, та підготовка педагогічних кадрів, які б на високому рівні вміли використовувати інтегрований підхід в освітньому процесі, надавати дитині комплексні знання, спонукати учнів до власних пошуків і відкриттів.

Актуальною також для освіти України в цілому і системи Малої академії наук, зокрема, $€$ проблема пошуку та впровадження інноваційних педагогічних технологій 3 розвитку інтересу та здібностей до дослідницької діяльності учнів молодшого шкільного віку, виховання творчої особистості, імплементації наукової освіти в сучасний освітній процес.

3 цією метою у 2017 році на базі Національного центру «Мала академія наук України» було створено ДИТЯЧУ АКАДЕМІЮ «ФУТУРУМ»- освітній простір для дітей 6-10 років, метою якого $є$ популяризація наукової освіти серед учнів молодшого шкільного віку, створення умов для реалізації творчого потенціалу дитини, розвитку іiі 248 
компетентностей та гнучких навичок шляхом дослідно-орієнтованого навчання в інтерактивному науково-освітньому просторі.

Навчання здійснюється за комплексною програмою «Людина. Світ. Наука», яка містить основи наукових знань 3 природничих та гуманітарних дисциплін (фізики, астрономії, хімії, біології, географії, історії, інженерії, риторики), а також за програмою «Мова. Світ. Наука», в основі якої закладена методика CLIL (Content and Language Integrated Learning) - предметно-мовне інтегроване навчання.

Отже, надання комплексних знань із впровадженням інтегрованого підходу до навчання $є$ ключовими аспектами навчально-виховного процесу Дитячої академії «Футурум».

У Великому тлумачному словнику сучасної української мови зазначається, що «інтеграція це - доцільне об'єднання та координація дій різних частин цілісної системи» [1, с. 401].

На думку Н. Костюк, «інтеграція - це процес взаємодії елементів із заданими властивостями, що супроводжується встановленням, ускладненням і зміцненням істотних зв'язків між цими елементами на основі достатньої підстави, в результаті якої формується інтегрований об'єкт (цілісна система) з якісно новими властивостями, у структурі якого зберігаються індивідуальні властивості вихідних елементів» [2, с. 9].

Ці концептуальні поняття про інтеграцію активно використовуються в освітній галузі для встановлення зв'язків між окремими дисциплінами. Інтеграцію в освіті розглядають, наприклад, «як різновид наукової інтеграції, що здійснюється у межах педагогічної теорії і практики; як вищу форму єдностей цілей, принципів, змісту, форм організації процесу навчання та виховання» [3].

У Дитячій академії «Футурум» інтегровані процеси здійснюються різними шляхами. Одним із них $є$ розроблення нестандартних занять, нових форм роботи з дітьми, зокрема (див рис.1) :

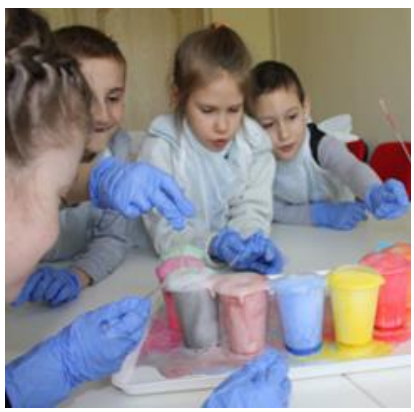

Рис. 1. 
- інтегрованого заняття, на якому один викладач впроваджує метод міжпредметних зв'язків з метою різновекторного висвітлення проблеми. Наприклад, тема заняття про воду може містити знання з хімії, біології, фізики, географії (див рис. 2):

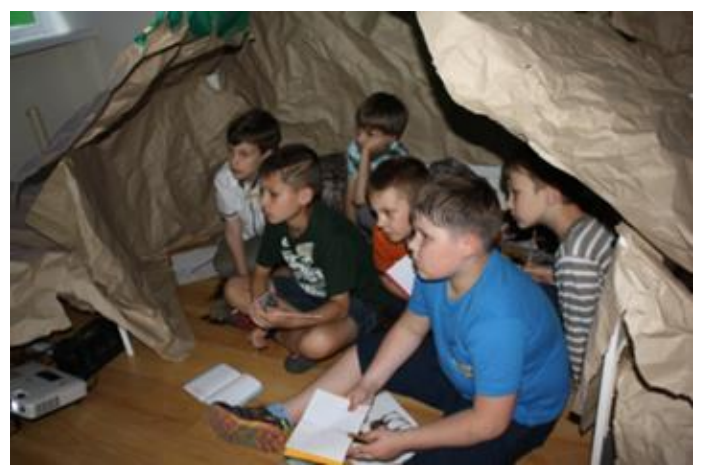

Pис. 2.

- бінарного заняття, яке проводять два викладачі - фахівці з різних галузей знань. Така творча співпраця педагогів природньо надихає учня до подібної колегіальності, активної роботі на занятті, а висвітлення теми на межі двох дисциплін стає подальшим ресурсом для дитини цілісно пізнавати світ. Наприклад, на бінарному занятті з хімії і біології «Як працює травнева система людини?» діти пізнають про органи травлення і проводять досліди і дізнаються, у яких продуктах містяться білки, жири, углеводи, а на занятті «Наука і цивілізація. Кам'яна доба» всі учасники навчального процесу стають «живими героями» цього періоду.

- STEM-заняття, основою для якого стає інтеграція природничих наук в інженерну творчість. Так на занятті 3 інженерії, зокрема, практикуються творчі конструювання, учням пропонуються технологічні карти, інструкції, схеми для вирішення завдання-виклику. Наприклад, вивчаючи поняття «електричний струм», діти виготовляють мінісвітлофор;

- заняття у формі проєкту, метою якого є залучення учнів до систематизації набутих знань, створення власних продуктів, командної роботи. Для прикладу, юні науковці мають практику виготовлення лепбуків на занятті, протягом місяця брати участь у спільному 
навчальному проєкті «Давній Світ». Такий вид діяльності розвиває навички критичного мислення, співпраці, спілкування, міркування, синтезу та стійкості в умовах обмеженого часу та визначеної мети;

- навчальної екскурсї, коли навчання відбувається за межами закладу в умовах природного ландшафту, музею, наукової установи тощо. Учні академії учні мають досвід занять на базі Національного музею історії України, Національного науково-природничого музею НАНУ, Головної астрономічної обсерваторії НАНУ, Астрономічної обсерваторії та Астрономічного музею Київського національного університету імені Тараса Шевченка, Національного ботанічного саду імені М. М. Гришка НАНУ тощо. Атмосфера наукових закладів і установ, наявність різних видів наочності $\epsilon$ сильними впливовими засобами донесення до учнів необхідних для формування понять про пізнавані об'єкти чуттєвих даних, явищ дійсності. Відбувається синтез раціонально-теоретичного та чуттєво-емпіричного знання;

- навчальної квест-екскурсї̈, коли на занятті відбувається поєднання елементів гри та екскурсії, діти отримують від гідавикладача певні завдання, занурюються в атмосферу часу, мають визначення мети, до якої повинні прийти всі учасники квесту. Наприклад, розроблена викладачами 3 риторики i географії квестекскурсія «Історичні цікавинки навколо Дитячої академії «Футурум»: що тут було 100 років тому» містить завдання для дітей як 3 історії рідного міста, так і загальних знань з історії України, української мови та літератури. Крім того, учні на практиці навчаються орієнтуватися за картою, використовувати компас, щоб віднайти потрібний об'єкт. Квест-екскурсія сприяє як цікавому засвоєнню набутих знань, розвитку ерудиції, так і колективному співпереживанню і командоутворенню;

-музейного заняття, які містять елементи гри i змагання 3 врахуванням постійної експозиції музею. Основою якісного проведення музейного заняття є підготовка викладача, який наразі виступає в ролі не лише педагога, наукового наставника, тьютора, а й музейного педагога-інтерпретатора, який має змусити кожен експонат «розмовляти» 3 учнем. На сьогодні перспективним для проведення практичних занять із учнями академії $\epsilon$ новий науковий простір перший державний Музей науки Малої академії наук України, де в доступній формі продемонстровано найважливіші наукові здобутки людства, їхні закони та взаємодія. Основною метою музейних занять $є$ формування в учнів навичок самостійно здобувати знання, а саме інформацію 3 першоджерела зазначеного експоната, удосконалювати навички пошукової роботи, співпраці в малих групах. 
У такий спосіб, на основі багатосторонніх міжпредметних зв'язків закладається фундамент для пізнавальної активності, формування в учнів умінь комплексного бачення навчальних предметів, цілісності наукових знань, проблем реальної дійсності, практичних підходів до їх розв'язання, взаємозв'язків різних аспектів життя. Відбувається розвиток важливих особистих навичок - творчого, критичного мислення, адаптації, комунікації та співпраці.

\section{Література:}

1. Великий тлумачний словник сучасної української мови/уклад. i голов. ред. В. Т. Бусел. Київ: Ірпінь: ВТФ «Перун». 2001. 1440 с.

2. Костюк Н. Т. Об'єктивна зумовленість і діалектика інтеграції сучасного наукового знання. Київ: Вища школа. 1998. 327 с.

3. Сідова Н. В. Інтеграція в освіті. Інтегроване навчання в Новій українській школі. URL: https://vseosvita.ua/library/integracia-v-osvitiintegrovane-navcanna-v-novij-ukrainskij-skoli-166667.html (дата звернення: 12.07.2021).

4. Концепція Нової української школи. URL: https://mon.gov.ua/ storage/app/media/zagalna\%20serednya/nova-ukrainska-shkolacompressed.pdf (дата звернення: 12.07.2021). 